\title{
Characterization of carotid plaques with a new CT technique
}

\author{
Arnoud van der Laarse · Jeroen J. Bax • \\ Ernst E. van der Wall
}

Received: 3 June 2008/Accepted: 3 June 2008/Published online: 18 June 2008

(C) The Author(s) 2008

Characterization of atherosclerotic plaques in the coronary, carotid or peripheral arteries in vivo is clinically highly relevant. In particular, identification of vulnerable plaques is of utmost importance because of the high risk to precipitate acute thrombotic occlusion [1, 2]. Several techniques are being used nowadays to define the pathology of coronary plaques such as cardiovascular magnetic resonance imaging (CMR) [3-6], intravascular ultrasound (IVUS) [7], optical coherence tomography [8], and multi-slice computed tomography (MSCT) [9-11]. The latter technique combines a number of advantages, such as noninvasiveness and rapid testing, but the downside is that patients are exposed to high levels of radiation. However, recent MSCT systems that have become available, operate at high speed thereby limiting the radiation burden. When looking at the algorithms for dose reduction, the use of ECG pulsing, a reduced tube voltage of $100 \mathrm{kV}$, and the sequential scan mode are independent predictors for a reduced dose. The effect of the sequential scan mode is largest, followed by the reduced tube voltage of $100 \mathrm{kV}$.

In the paper recently published by de Weert and colleagues [12], the human atherosclerotic carotid plaque is recorded in vivo by MSCT, and analyzed off-line to determine plaque volume and composition.

A. van der Laarse · J. J. Bax · E. E. van der Wall ( $\square)$ Department of Cardiology, Leiden University Medical Center, Leiden, The Netherlands

e-mail: e.e.van_der_wall@lumc.nl
Secondly, the inter-observer variability has been determined. Four patient groups were included in the study, categorized by their carotid artery stenosis grade: $0-29 \%, 30-49 \%, 50-69 \%$, and $70-99 \%$. By manually drawing regions of interest (ROI) the pixel intensities within a ROI were divided into three categories: lipid core $<60$ Hounsfield Units (HU), fibrous tissue 60-130 HU, and calcification $>130$ HU. Before consensus was reached with regard to the lesion length, location of bifurcation and lumen attenuation, inter-observer differences and coefficients of variation (COV) were quite high and interclass correlation coefficients (ICC) were quite low. But if consensus was reached with regard to the lesion length, location of bifurcation and lumen attenuation, inter-observer differences and $\mathrm{COV}$ decreased, and ICC increased, to reach values almost similar to those observed after analysis of intraobserver differences.

The problems encountered with this technique are: (1) how to differentiate between a normal arterial wall and a slightly thickened arterial wall, (2) how to outline reliably the outer border of the artery where adventitial fat should not be confused with atheromatous lipid in the plaque, and (3) how to differentiate the contrast-enhanced lumen from atherosclerotic plaque. Although the present study lacks validation with histopathological techniques, previous studies of the same group have shown a good correlation between area measurements of arteries recorded by MSCT and histology [13, 14]. 
The use of MSCT for quantitative assessment of atherosclerotic lesion severity of large arteries in terms of fibrous tissue, lipid, and calcifications will contribute to the rapidly increasing popularity of examinations with MSCT.

Open Access This article is distributed under the terms of the Creative Commons Attribution Noncommercial License which permits any noncommercial use, distribution, and reproduction in any medium, provided the original author(s) and source are credited.

\section{References}

1. de Nooijer R, Verkleij CJ, von der Thüsen JH et al (2006) Lesional overexpression of matrix metalloproteinase-9 promotes intraplaque hemorrhage in advanced lesions but not at earlier stages of atherogenesis. Arterioscler Thromb Vasc Biol 26:340-346

2. van Lennep JE, Westerveld HT, van Lennep HW, Zwinderman AH, Erkelens DW, van der Wall EE (2000) Apolipoprotein concentrations during treatment and recurrent coronary artery disease events. Arterioscler Thromb Vasc Biol 20:2408-2413

3. Yuan C, Beach KW, Smith LH, Hatsukami TS (1998) Measurement of atherosclerotic carotid plaque size in vivo using high resolution magnetic resonance imaging. Circulation 98:2666-2671

4. Corti R, Fayad ZA, Fuster V et al (2001) Effects of lipidlowering by simvastatin on human atherosclerotic lesions. A longitudinal study by high-resolution, noninvasive magnetic resonance imaging. Circulation 104:249-252

5. Langerak SE, Vliegen HW, de Roos A et al (2002) Detection of vein graft disease using high-resolution magnetic resonance angiography. Circulation 105:328-333
6. Takaya N, Cai J, Ferguson MS et al (2006) Intra- and interreader reproducibility of magnetic resonance imaging for quantifying the lipid-rich necrotic core is improved with gadolinium contrast enhancement. J Magn Reson Imaging 24:203-210

7. Nasu K, Tsuchikane E, Katoh O et al (2006) Accuracy of in vivo coronary plaque morphology assessment. A validation study of in vivo virtual histology compared with in vitro histopathology. J Am Coll Cardiol 47:2405-2412

8. Chia S, Raffel OC, Takano M, Tearney GJ, Bouma BE, Jang IK (2008) Association of statin therapy with reduced coronary plaque rupture: an optical coherence tomographic study. Coron Artery Dis 19:237-242

9. Pundziute G, Schuijf JD, Jukema JW et al (2007) Prognostic value of multislice computed tomography coronary angiography in patients with known or suspected coronary artery disease. J Am Coll Cardiol 49:62-67

10. Schuijf JD, Pundziute G, Jukema JW et al (2006) Diagnostic accuracy of 64-slice multislice computed tomography in the noninvasive evaluation of significant coronary artery disease. Am J Cardiol 98:145-148

11. Schuijf JD, Wijns W, Jukema JW et al (2006) Relationship between noninvasive coronary angiography with multislice computed tomography and myocardial perfusion imaging. J Am Coll Cardiol 48:2508-2514

12. De Weert TT, de Monye C, Meijering et al (2008) Assessment of atherosclerotic carotid plaque volume with multidetector computed tomography angiography. Int J Cardiovasc Imaging. doi:10.1007/s10554-008-9309-1

13. De Weert TT, Ouhlous M, Zondervan PE et al (2005) In vitro characterization of atherosclerotic carotid plaque with multidetector computed tomography and histopathological correlation. Eur Radiol 15:1906-1914

14. De Weert TT, Ouhlous M, Meijering E et al (2006) In vivo characterization and quantification of atherosclerotic carotid plaque components with multidetector computed tomography and histopathological correlation. Arterioscler Thromb Vasc Biol 26:2366-2372 